International Journal of Zoological Investigations

Contents available at Journals Home Page: www.ijzi.net

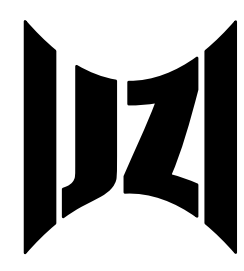

ISSN: 2454-3055

\title{
Effects of the Parasite Loxothylacus texanus on the Agonistic Behavior of the Crab Callinectes rathbunae
}

Vázquez-López Horacio ${ }^{\mathrm{a}}$, Escamilla-Montes Ruth ${ }^{\mathrm{b}}$, Diarte-Plata Genaro ${ }^{\mathrm{b}}$, Cházaro-Olvera Sergio ${ }^{\mathrm{a}}$, Rodríguez-Varela Asela del Carmena, Franco-López Jonathanc, Chávez-López Rafaela and MoránSilva Ángela

aGrupo Académico y de Investigación Acuática (GAIA). Facultad de Estudios Superiores Iztacala, Universidad Nacional Autónoma de México

bCIIDIR, Unidad Sinaloa, Instituto Politécnico Nacional, México

cLaboratorio de Ecología, Facultad de Estudios superiores Iztacala, Universidad Nacional Autónoma de México

*Corresponding Author

Received: $21^{\text {st }}$ February, 2020

Accepted: 24th April, 2020

Published online: 30th April, 2020

https://doi.org/10.33745/ijzi.2020.v06i01.010

\begin{abstract}
This study presents the changes in the agonistic behavior of the crab Callinectes rathbunae parasitized by Loxothylacus texanus, collected in Alvarado Lagoon, Mexico. Alive parasitized crabs were observed in the laboratory for their behavior. Hepatopancreas of the parasitized crabs were fixed for examination. Both crabs with virgin and mature externa were monitored, and their degree of aggressiveness compared. The aggressiveness of the parasitized crabs decreases according to the parasite development. A possible relation with behavior and hepatopancreas infestation is given. In this study it is observed that the crabs with virgin externa are more aggressive than organisms with mature externa. Also, the agonistic behavior of the host decreases according to the development of the parasite. This is the first report where behavioral changes of parasitized crabs caused by a rhizocephalan, degree of development of the parasite and hepatopancreas atrophy are described.
\end{abstract}

Keywords: Aggressiveness, Behavior, Histology, Loxothylacus, Parasitism, Rhizocephala, Hepatopancreas, Callinectes rathbunae

Citation: Vázquez-López Horacio, Escamilla-Montes Ruth, Diarte-Plata Genarob, Cházaro-Olvera Sergio, RodríguezVarela Asela del Carmen, Franco-López Jonathan, Chávez-López Rafael and Morán-Silva Ángel: Effects of the parasite Loxothylacus texanus on the agonistic behavior of the crab Callinectes rathbunae. Intern. J. Zool. Invest. 6 (1): 122$134,2020$.

https://doi.org/10.33745/ijzi.2020.v06i01.010 


\section{Introduction}

The Rhizocephala is a group of uniquely specialized parasites infesting a range of other Crustacea, mainly decapods. The adult parasite consists of an external reproductive body that connects through a stalk with a more or less extensive system of rootlets inside the host (Høeg, 1992; Høeg and Lützen, 1995; 1996). It is significant that the root system invades the neuroendocrine organs of the host before invading the digestive system (Høeg, 1995; Bresciani and Høeg, 2001). A female cypris infects the recently molted host by penetrating the soft exoskeleton, giving rise to an internal phase named "interna" that develops into a net of fine rootlets that will anchor and nurture the reproductive body of the parasite known as the "externa". After a variable growing period, when it reaches sexual maturity, the externa emerges, breaking the soft tegument of the internal surface of the host's abdomen. The externa is then fertilized by a male cypris and starts growing until the gonads contained in it mature and start releasing larvae (Høeg, 1992; Høeg and Lützen, 1995).

In the coastal lagoons of the Gulf of Mexico, one of the most important biotic factors that affect populations of crabs of the genus Callinectes, is the parasitism caused by rhizocephalan parasites (Crustacea: Rhizocephala) (Andersen et al., 1990; Alvarez and Calderón, 1996).

The parasitic castration, cease of shell shedding and hyperfeminization are some effects that this parasitic barnacle causes to its host (Høeg and Lützen, 1995; 1996). The parasite inhibits reproduction and moulting and in males a feminized behavior is shown (Alvarez and Calderón, 1996). Also, Vázquez-
López et al. (2006 b) reported paralysis, blindness and behavioral changes in $C$. rathbunae parasitized by $L$. texanus. The effects caused by L. texanus in C. rathbunae have been least studied. Based on what was found in the literature on the parasitic-host relationship (Rhizocephala-crabs), we believe that the agonistic behavior of crabs is altered according to the development of the root system of the parasite, within the hepatopancreas of the host, which is also affected. Keeping this in view, this work was aimed to describe the agonistic behavior of $C$. rahbunae with different degree of parasitism caused by L. texanus.

\section{Materials and Methods}

In the lagoon system of Alvarado, Veracruz, $C$. rathbunae parasitized by $L$. texanus were collected from commercial catches. In the sampling location, crabs with different levels of parasitism were fixed (virgin externa, parasites that do not produce larvae and mature externa, parasites that produce larvae) following the classification used by Wardle and Tirpak (1991) and Alvarez and Calderón (1996) for Callinectes sapidus parasitized by L. texanus. In addition an adult male and female which recently molted (to ensure that they were healthy organisms) were obtained from a local producer, serving as control organisms. All organisms were fixed by using an injection filled with a formaldehyde solution (Humason, 1972; Hammersen and Sobotta, 1980; Johnson, 1980; Paniagua and Nistal, 1983; Bell and Lightner, 1988; Bancroft and Gamble, 2008), in order to preserve the hepatopancreas and were transported to the Laboratory of Invertebrates, Faculty of Sciences at the 
National Autonomous University of Mexico (UNAM). All organisms were measured and sexed.

In the laboratory hepatopancreas dissection was performed on each specimen: a male and a female recently molted, a feminized male, four crabs with virgin externa and five with mature externa. The hepatopancreas were processed using standard techniques and subsequently $10 \mu \mathrm{m}$ thick tissue sections were obtained by using a manual microtome (American Optical). The sections were stained were with hematoxylineosin. The resulting slides were analyzed and images were taken from a compound microscope Olympus BX.

In the laboratory, the alive crabs were individually kept under culture conditions within recirculation water systems, with an initial salinity of $5 \%$, which then was gradually increased until it reached $15 \%$. Acclimation period lasted one week. Temperature at the laboratory was always at $27 \mathrm{C}$ and represented an average of the temperatures recorded at field, being the minimum $25 \mathrm{C}$ and the maximum $30 \mathrm{C}$. Salinity and temperature were daily measured. They were fed ad libitum every other day at different times, with fish fillet and/or chicken liver. The food remains were removed to avoid decomposition.

At the end of the acclimation period, the behavior of 113 parasitized crabs was monitored for six months, 93 with virgin externa and 20 with mature externa. The observations were made from 9:00 to 20:00 by the focal subgroups method, following the criteria proposed by Altmann (1974), Backwell et al. (2006) and De la CruzManjarrez and Vázquez-López (2015).
The categories of agonistic behavior considered in the present investigation were submission and threat and/or aggression (attack) (Jachowski, 1974; McGlone, 1986; Innocenti et al., 1998, 2003). The first (both sexes) were those who didn't show any sign of threat, aggression or defense or which were slow in their responses. The aggressive crabs (both sexes) were the ones that showed aggressiveness or defense. A Chi-square test $\left(\mathrm{X}^{2}\right)$ was used to compare frequencies of the number of externa. Another Chi-square test $\left(\mathrm{X}^{2}\right)$ was used to compare behavior categories (Sokal and Rohlf, 1981; Statistica Spreadsheet of Excel).

\section{Results}

The minimum carapace width from hosts was $5.8 \mathrm{~cm}$ and the maximum $9.67 \mathrm{~cm}$, with an average of $7.73 \pm 2.73 \mathrm{~cm}$.

The chi-square test (number of mature externa X20=17.86, $p>0.05 \quad \mathrm{X} 20.05,6=12.59$; number of virgin externa $X 20=44.69, p>0.05$ $X 20.05,6=12.59$ ) showed that the number of externa is related to the behavior of the parasitized crabs.

The chi-square test (mature externa vs virgin externa $\mathrm{X}^{2}=35.21 ; \quad \mathrm{df}=1, \quad p<0.001$ ) showed that the agonistic behaviors submission and threat and/or aggression (attack) are related to the development of the externa.

The hepatopancreas of unparasitized crabs consisted of an arrangement of tubules in close proximity, each one with a lumen with the shape of an $X$ and an interstitial space between them (Fig. 1). The tubules presented an average length of $169.06 \pm 40.18 \mu \mathrm{m}$. Roots from L. texanus were observed in those slices from crabs with a virgin externa. They were 
positioned both transversally and logitudinally, infiltrated among the tubules, separating them, but despite this, the structure of the hepatopancreas was still

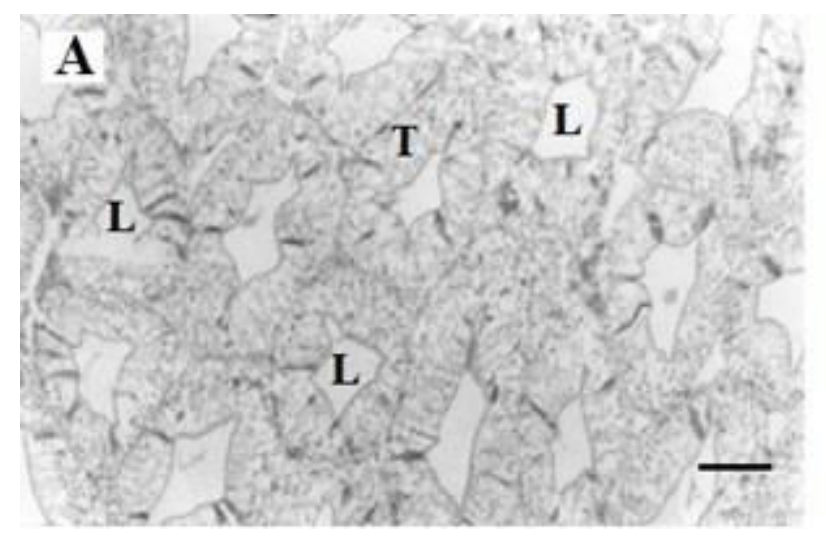

recognized (Fig. 2 A). In those slices from crabs with a mature externa the tubules were more separated because of the roots from $L$. texanus (Fig. 2 B-G).

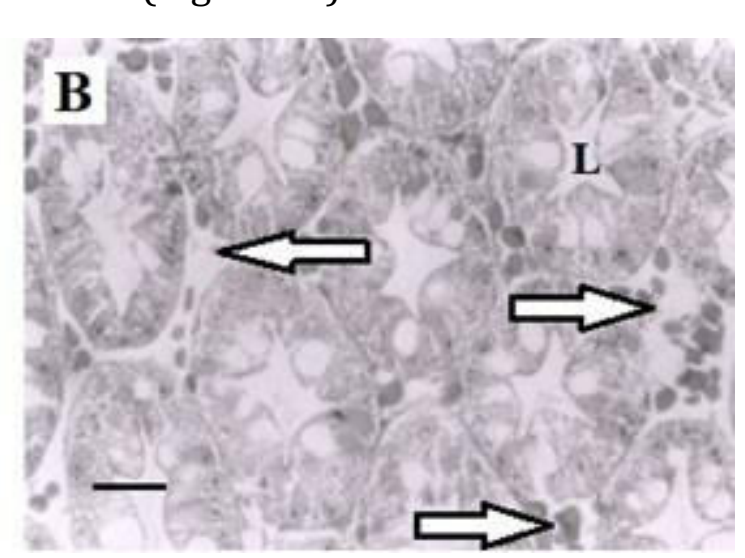

Fig. 1 (A): Healthy hepatopancreas from a female crab C. rathbunae that has recently shedded its shell. L= lumen, $\mathrm{T}=$ tubule. Scale bar $50 \mu \mathrm{m}$. (B) Healthy hepatopancreas from a male crab C. rathbunae . L= lumen, the arrows indicate the interstitial spaces. Haemotoxylin and eosin. Scale bar $50 \mu \mathrm{m}$.

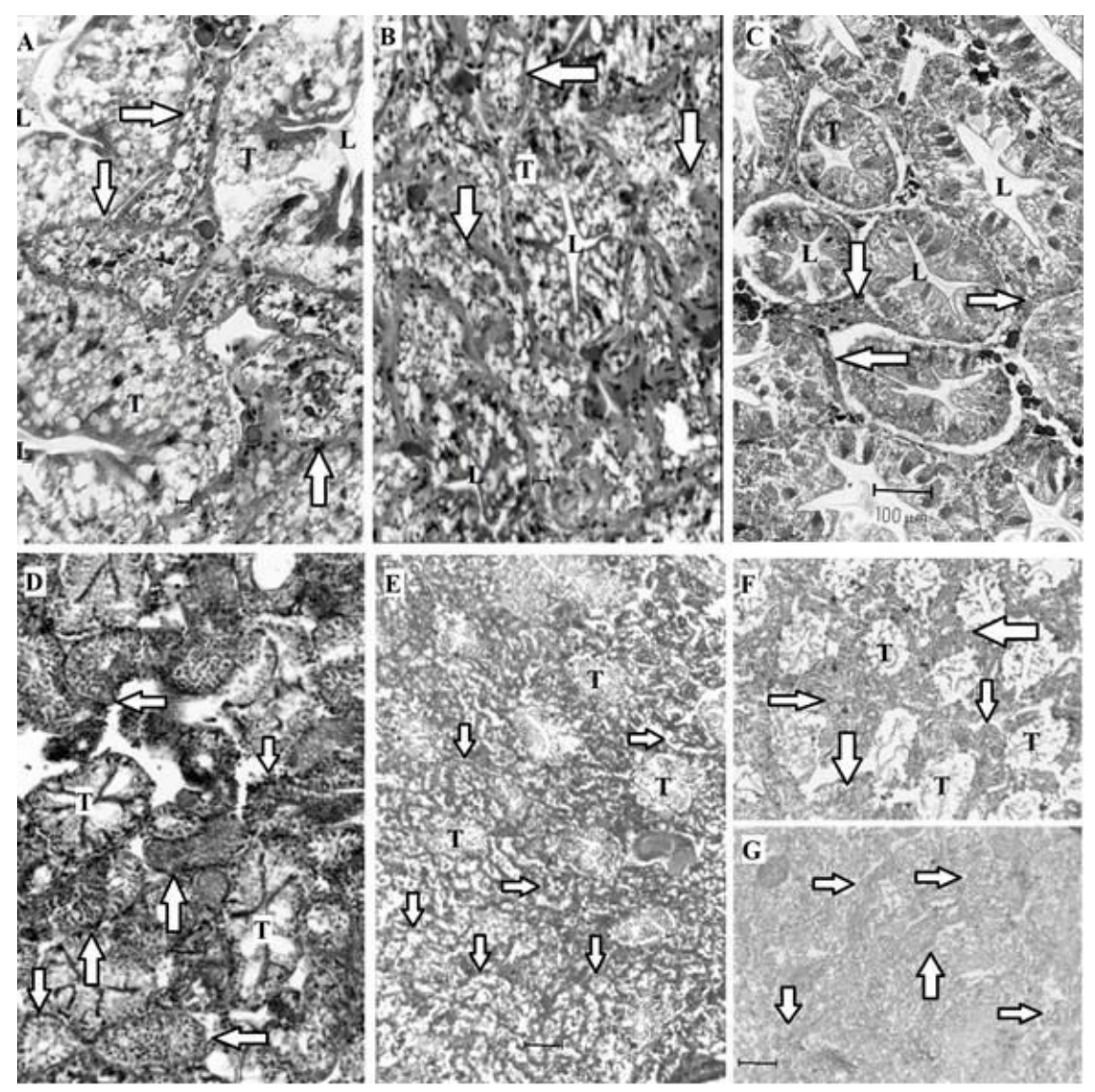

Fig. 2: Slices of the hepatopancreas of C. rathbunae affected by L. texanus. (A) male with 1 virgin externa, (B) female with 1 mature externa, (C) male with 1 mature externa, (D) female with 2 mature externae, (E) female with 3 mature externae, ( $\mathrm{F}$ and $\mathrm{G}$ ) male with 4 mature externae. $\mathrm{T}=$ tubule, $\mathrm{L}=$ lumen, the arrows show the roots from L. texanus. Scale bar: A and B $10 \mu \mathrm{m}, \mathrm{C} 100 \mu \mathrm{m}, \mathrm{D}-\mathrm{G} 50 \mu \mathrm{m}$. 


\section{Crabs with virgin externa:}

Hosts with one and four externae were found. The specimens with one and two virgin externas (51 females and 31 males) showed aggression and attack as the one observed in healthy crabs from the genus Callinectes. These crabs, independently of their sex, displayed a defensive position when being in front of another individual, and when a person or object approached them, they would immediately attack.

When food was brought to them, the crabs exhibited fast movements from both the antennules and the mouth appendages, going straight towards it. Other recorded behaviors were constant grooming as healthy organisms do, however, they would raise their abdomen repeatedly to introduce a pereiopod (second, third or fourth) and seemed as they were cleaning the externa, and they would also perform movements as if they were burying sediment just as healthy crabs do.

Those crabs with three or four externae (nine females and two males) were observed raising their abdomen two or three times during the observation period and would introduce a pereiopod (second, third or fourth), occasionally displaying movements as if they were burying sediment. When food was given to them, they showed the same behavior as other crabs with one and two externae, displaying fast movements from the antennules and mouth appendages, moving towards the food as well as showing an aggressive behavior. One behavior observed in all 93 organisms, was that once they were fed, they would stay away from the food and start grooming themselves. It was noted that the swimming appendages fold upwards so that the animals lose the ability to swim.

\section{Crabs with mature externa:}

Host crabs presented one to four externae. The crabs with a mature externa (20) showed a completely different behavior from those crabs with a virgin externa. The organisms with one and two externae (eight females and nine males) were less aggressive, being more evident in those crabs with three and four externae. Even in some cases, the researcher could put his hand near these animals without getting any type of aggressive response. On the other hand, crabs with a virgin externa (20), tended to be more voracious, feeding more than once during the observation period.

During the feeding process, the movement of the antennules and the mouth appendages were not as vigorous; the individuals consumed more food but ingested it slower than those crabs with a virgin externa. The organisms with three and four externae moved around the entire tank until they could find food.

Another difference was that the frequency of grooming was much less, even the crabs with three and four externae did not clean their carapace even when accumulated sediment was observed on them. Those 20 crabs did not display any attempt to bury themselves in the sediment and remained longer periods of time without moving from the same place, showing constant movement from the abdomen as females with an ovigerous mass do when they are oxygenating it, they kept themselves leaning on the tank's wall, raising the posterior part of their bodies. They were also seen cleaning the externae with one of the pereiopods (second, third or fourth). No mobility was observed in the swimming pair of legs of these 20 crabs. 
Throughout the experiment some of the crabs with three or four externa died when they were placed in the tanks with different salinities of 15 ups, which was not recorded with those crabs that had a virgin externa.

\section{Discussion}

Jachowski (1974) used healthy crabs from the species Callinectes sapidus Rathbun, 1896 during the intermolt cycle. He performed some experiments in order to keep track of their agonistic behavior, observing that males were aggressive and fought among themselves for food and individual space, and displayed this behavior even with non-receptive females.

Same author observed that both sexes fight over food and when one of these organisms (both sexes) holds an object in one of its claws and feels threatened by another individual it fights vigorously using the other claw. This author also mentions that crabs are more aggressive with rivals from the same size and are less aggressive with smaller crabs because they can dominate them easily. The level of aggression decreases in those individuals that are about to start the molt cycle and females also are less aggressive just after having shedded their shells, some of them even get closer to males in order to mate.

Other researchers have observed that juvenile organisms of Callinectes sapidus are aggressive, react to external stimuli, such as foreign objects and they are cannibals, and these behaviors persist in adult stages (Hines and Ruiz, 1995; Clark et al., 1999; Hines, 2007; Reichmuth et al., 2011).

Pedetta et al. (2010) observed the agonistic behavior of adult males of Chasmagnathus granulatus (Neohelice granulata Dana, 1851) during the intermolt cycle, describing it as very aggressive. These same authors observed very dynamic combats between individuals and also reported that isolation increases aggressiveness in crabs.

It was observed that in those parasitized crabs, the agonistic behavior decreased consistent with the maturation process of the externa. In the corresponding histologic slices it was observed that in the hepatopancreas affected by three or four mature externas, the tubules were separated from each other by the presence of many roots and in some cases even the tubule's shape was lost, which did not occurred in those hepatopancreas affected by a virgin externa.

Crabs of species Callinectes sapidus parasitized with virgin externae of $L$. texanus have an already heavily infiltrated hepatopancreas with the rhizocephalan rootlets, most of which are solid and with a mean diameter of 20-60 $\mu \mathrm{m}$. At this stage of parasitization the hepatopancreatic tubules start to become separated by the numerous rootlets. The intertubular connective tissue appears still somewhat organized. The hepatopancreas of a crab carrying a mature externa of $L$. texanus shows a greater separation between hepatopancreatic tubules. Most of the parasite's rootlets have developed a lumen and there are disperse remnants of connective tissue in the intertubular spaces. In the tubules many binucleate cells can be seen (Bortolini and Alvarez, 2008).

Histological changes were routinely observed in the structure of hepatopancreas of infected crabs while gills showed no apparent changes from parasitization. The hepatopancreas from apparently healthy crabs consists of tubules separated by haemal 
spaces which contain connective tissue and circulating haemocytes (Powell and Rowley, 2008), meanwhile the hepatopancreas or perigastric organ from healthy organisms is a tubular gland that occupies most of the cephalothorax, being enclosed inside a thin membrane. It is highly compressed, with small spaces among the tubules and each tubule's epithelium consists of five cell types called: embryonic, fibrillar, midget, reserve and secretory cells, based on the size and each tubule shows a lumen with an $X$ shape (Ramadevi et al., 1990; Cuartas et al,. 2002; Bortolini and Alvarez, 2008; FranceschiniVicentini et al., 2009; Cervellione et al., 2017).

Sacculinids such as $L$. texanus have the most extensive root systems in the Rhizocephala. The system lacks any main parts and the randomly ramifying rootlets can penetrate into every conceivable part of the body, including many internal organs and all or most of the appendages (Høeg and Lützen, 1985; Bresciani and Høeg, 2001).

The degree to which the roots proliferate through the host varies extensively, in most Rhizocephala, including all Kentrogonida, the roots infiltrate the hepatopancreas, but apart from this the ventral nerve cord represents the only other organ frequently reached by roots. This corresponds to the fact that the root system has two principal functions, first, absorption of nutrients and second, host control affected through perturbations to the neuroendocrine system of the host (Høeg, 1995). On the other hand, the external sac of the parasite masquerades as the egg mass of their host and the parasite often changes the behavior of male hosts to make them less aggressive and more like pre-ovigerous females (Shields, 2012).
Bishop and Cannon (1979), observed the behavior of crabs Portunus pelagicus (L.), parasitized by Sacculina granifera Boschma, 1973, finding that the parasitized males were more active while being alone during the feeding process. They also mention that general integument cleaning behavior was identical for both normal and parasitized crabs, although parasitized crabs, having more epizoics than normal crabs, sac-grooming behavior was found to vary in intensity in relation to the type of stance and appendages used and the duration of grooming during a 30 min observation. During low intensity sacgrooming behavior, the body was raised 2 or 3 $\mathrm{cm}$ above the substratum and the cephalothorax was held nearly horizontal to the substratum. While the abdomen was extended slightly away from the externa, the sac and surrounding area were lightly prodded with the dactyls of only the third walking leg. In more than half of the observations the other walking legs were concurrently used for body care, the abdomen was varyingly extended and abdominal flapping was frequently accompanied by medial movement of the pleopods.

Ritchie and Høeg (1981) reported that porcelain crabs parasitized by Lernaeodiscus porcellanae Müller, 1862 helped the parasite in delivering nauplii larvae, by holding on to a rock and rising and shaking their bodies energetically against the current. Høeg (1995) reported that crabs Carcinus maenas parasitized by Sacculina carcini groom themselves less than those organisms capable of burying in the sediment and that the crabs with a mature externa tend to raise their bodies, moving the abdomen with back and forth motions. 
Charybdis (Goniohellenus) longicollis Leene, 1938, parasitized by Heterosaccus dollfusi Boschma, 1960 clean their externa with the second, third and fourth periopod as they contract their abdomen, keeping the externa clean and oxygenated, just like ovigerous females do. The parasitized crabs with a mature externa, do not show movement from their last periopods. A common behavior observed in unparasitized crabs is burying themselves in the sediment, which does not occur in parasitized crabs because it is difficult for them to do it, as they cannot coordinate their movements (Innocenti et al., 1998).

Regardless of their sex, C. rathbunae are less aggressive as they develop their externa, being less aggressive those organisms that present three or four mature externa. Those crabs with mature externa lose their ability to bury; they do not groom themselves and display vigorous abdomen movements in order to oxygenate the externa. The parasitized individuals lose their ability to swim as their swimming legs lose their mobility (Vázquez-López et al., 2006 a, b; 2012; Vázquez-López, 2010).

McGlone (1986) mention that the agonistic behavior is based on three major criteria: physiological mechanisms, motor patterns shown during agonistic behavior, and the environmental situation. So if it is known that the roots of the interna affect the neuroendocrine organs, it is possible that the presence of $L$. texanus also affects the host's hormonal levels. Although hormonal levels were not measured in the present investigation, because it is a mainly descriptive work and is not the main objective, it is important to mention the following, since it can reinforce what was observed: Different types of parasites modify their hosts' behavior, combined with the manipulation; the parasites create deep effects in their hosts. Most of the studies demonstrate that the presence of parasites decrease the ability of the host's performance (Moore, 2013; McElroy and de Buron, 2014).

Parasite-induced modifications of host behavior are known from a wide range of host-parasite associations, in many cases, these behavioral changes are thought to be adaptive and benefit the parasite by increasing its probability of successful transmission (Poulin, 1994, 2013). The evolutionary origins of host manipulation by parasites may go all the way back to the establishment of complex life cycles (Smith, 1980; Moore, 1984; Poulin, 1994), but the mechanisms underlying ethological changes are by no means well characterized.

Evidence is accumulating that the biogenic amine serotonin (5-hydroxytryptamine, 5-HT) is involved in several host-parasite systems (Helluy and Thomas, 2003). 5-HT is present in the crustacean nervous system (Livingstone et al., 1981; Elofsson et al., 1982; Laxmyr, 1984) It may be that $5-\mathrm{HT}$ occurs in all animal kingdom and has an important role in the regulation of a very wide range of physiological processes (Walker, 1984).

There is evidence that shows changes in the levels of serotonin in a range of hosts, from crustaceans to mammals, which are infected by a wide diversity of parasites like protozoans and helminths. Recent studies reveal that when crustaceans and other parasitized and healthy invertebrates are injected with serotonin, there is a change in their behavior, an increase in their aggressiveness and a trend to fight with 
dominant individuals, so it has been concluded that 5-HT plays an important role in the behavior. It has been observed that in a big pair of neurons found in the first abdominal node in crustaceans there are serotonin neurosecretions that seem to act over the exoskeleton muscles, the bending and over the motor system which has to do with the fight or flight response (Edwards and Kravitz, 1997; Huber et al., 1997; Helluy and Thomas, 2003; Wu and Cooper, 2012). The serotonin and dopamine (DA) are neurotransmitters in crustaceans that control and modulate many physiological functions, including reproduction and ovarian maturity, whereas the serotonin can stimulate ovarian development triggering the release of gonadal inhibition hormone (GIH). DA can suppress reproduction, triggering the release of a suppressing gonad hormone from X-organsinus-gland complex, as well as inhibit GSH (Sarojini et al., 1995 a, b; Khornchatri et al., 2015).

Rojas and Ojeda (2005) inoculated crabs of Hemigrapsus crenulatus H. Milne-Edwards, 1837 with the acantocephalus Profilicollis antarcticus Zdzitowiecki, 1985, revealing an increase in the levels of DA circulating in the hemolymph and an absence of 5-HT. These authors mention that this benefits the parasite, as crabs are less aggressive they become an easy target for gulls, which are the final host. Sneddon et al. (2000) conducted fights between healthy crabs of the species Carcinus maenas. No crabs were fed and they were individually isolated to encourage aggressive behaviour. Only blood samples were taken from the control crabs and they were not disturbed further. On the other hand, blood samples from the crabs that were used in the fights were taken before and after each fight. These authors mention that within the hemolymph samples from the control individuals only DA was detected, while in the samples from the fighting crabs, 5-HT, octopamine and DA were registered. DA levels were significantly different among winners and losers during the $7^{\text {th }}$ and $9^{\text {th }}$ day of isolation and lower levels of DA were detected in those crabs that had lost the fights.

Most of rhizocephalan parasites infiltrate their roots into the hepatopancreas, the stomach and the ventral nervous cord; in saculinids, the ventral ganglion mass represent the main objective for the roots, whereas the infiltration of gonads, brain and androgenous gland are facultative and the extent of this infiltration is variable and it rarely reaches the ocular stems where the sinus glands are located. It is significant that the root system invades the neuroendocrine organs of the host before invading the digestive system.

If by any chance the defense system of the host fights the roots during growth, these will remain small (Høeg, 1995; Bresciani and Høeg, 2001), even though it has been reported that the roots of Sacculina carcini avoid the defense mechanism of Carcinus maenas and present immunity against the infectious agents which are thought to be present in crabs and that act as immune agents (Russell et al., 2000).

Andrieux et al. (1981) injected a raw extract of parasitized $S$. carcini and hemolymph of parasitized Carcinus maenas into healthy crabs of Carcinus mediterraneus (Carcinus aestuarii Nardo, 1847) and Carcinus maenas, observing that both substances affected the protein composition from the 
hemolymph of healthy crabs and there were effects such as the cessation of moult, Vázquez-López (2010) mention that it can be deduced that the roots of Loxothylacus texanus possibly secrete some infectious agent that can act locally in the innervations of the natatory legs of C. rathbunae where it can permanently block the transmission of the synapses. Regarding this, Høeg (1995), Robles et al. (2002), Rojas and Ojeda (2005) and Vázquez-López et al. (2006 b) mention that parasites represent a high metabolic maintenance cost for the host and that the altered physiological conditions benefit the parasites. Alvarez et al. (2002) observed that Loxothylacus texanus affect significantly the osmoregulation process in C. rathbunae, although Reisser and Forward (1991), mention that Loxothylacu spanopaei Gissler, 1884 does not affect the osmoregulation of Rhithropanopeus harrisii Gould, 1841.

Robles et al. (2002) argue that Loxothylacus texanus during the virgin externa and immature externa phases do not affect the respiratory rate of $C$. rathbunae, but mature parasites (mature externa) do affect the breathing rate from 57 to $139 \%$, increasing it despite the salinity.

Environmentally, trematodes Leucochloridium spp affect the shape, coloration and tentacle size of some species of snails as well as their behavior, in order to become easy targets for birds and to spread themselves. The parasitic protozoan Toxoplasma gondii affect rat behavior so they can be consumed by cats to complete their life cycle (Poulin, 2010). The acantocephalus Profilicollis antarcticus (Zdzitowiecki, 1985) causes phenotypic (changes in color) and behavioral changes (constant movements) in the crab Hemigrapsus crenulatus (Milne-Edwards
1837). This makes parasitized organisms an easy target for predators such as gulls, allowing these parasites to complete their life cycle and be able to spread themselves in the environment (Pulgar et al., 1995; Haye and Ojeda, 1998).

Thompson and Kavaliers (1994) proposed that in studies of parasitism it is possible to integrate various levels of biological organization, allowing links among behavior, physiology and ecology. Haye and Ojeda (1998) mention that there exist a close relationship between behavior and physiology, which supports the hypothesis that alterations of host behavior are correlated with changes in metabolic rates.

Based on what was previously stated by other authors, it can be suggested that Loxothylacus texanus suppresses the synapsis in the pair of swimming pereiopods to avoid the damage of the externa, it also causes a decrease in the serotonin levels which reduces aggressiveness and thus prevents any type of harm to the host and to the externa, and it also hinders the motor coordination of the host so it cannot bury itself and crush the externa; with all these actions, the parasite increases its chances of survival and continuity.

\section{Conclusion}

We concluded that initially $L$. texanus affects the hepatopancreas of $C$. rathbunae as it feeds itself from this organ. This is supported by the high amounts of roots found inside the hepatopancreas, which make this organ lose its structure and functionality. In the molt prior to the emergence of the externa virgin, $L$. texanus infiltrates the ventral nerve cord.

Once the virgin externa has emerged there is a decrease of agonistic behavior which 
could possibly coincide with the decrease of serotonin levels in the hemolymph and with the presence of dopamine, keeping the parasitized individuals passive, which makes the host save energy for its own benefit which in turn will be used by the parasite. L. texanus represents a huge metabolic burden for its host. This is the first report where behavioral changes of parasitized crabs by a rhizocephalan, degree of development of the parasite and hepatopancreas atrophy are described.

\section{Acknowledgement}

Horacio Vázquez-López thanks CONACyT for doctoral scholarship (No. 171618).

\section{References}

Altmann J. (1974) Observational study of behaviour: Sampling methods. Behaviour. 49:227-267.

Alvarez F and Calderón J. (1996) Distribution of Loxothylacus texanus (Cirripedia: Rhizocephala) parasitizing crabs of the genus Callinectes in the southwestern Gulf of México. Gulf Res. Rep. 9: 205-210.

Alvarez F, Alcaraz G and Robles R. (2002) Osmoregulatory disturbances induced by the parasitic barnacle Loxothylacus texanus (Rhizocephala) in the crab Callinectes rathbunae (Portunidae). J. Exp. Mar. Biol. Ecol. 278: 135-140.

Andersen ML, Bohn M, Høeg JT and Jensen PG. (1990) Cyprid ultrastructure and adult morphology in Ptychascus barnwelli new species and P. glaber (Cirripedia: Rhizocephala), parasites on semiterrestrial crabs. J. Crust. Biol. 10: 20-28.

Andrieux N, Herberts Ch and de Frescheville J. (1981) Relationshote-parasite entre les crustacés Carcinus et Sacculinacarcini: Effetd'extraits de parasite et de l'hémolymphe de crabe infesté sur le protéinogramme de crabessains. Ann. Parasitol. (Paris). 56: 441-448.

Backwell P, Jennions M, Wada K, Murai M and Christy J. (2006) Synchronous waving in two species of fiddler crabs. Acta Ethol. 9: 22-25.

Bell TA and Lightner DV. (1988) A handbook of normal penaeid shrimp histology. The World Aquaculture Society, Baton Rouge.
Bishop RK and Cannon LRG. (1979) Morbid behaviour of the commercial sand crab, Portunus pelagicus (L.), parasitized by Sacculina granifera Boschma, 1973 (Cirripedia: Rhizocephala). J. Fish Dis. 2: 131-144.

Bortolini JL and Alvarez F. (2008) Hepatopancreas alteration of the blue crab Callinectes sapidusby the rhizocephalan barnacle Loxothylacus texanus. J. Invertebr. Pathol. 99: 354-356.

Brancroft JD and Gamble M. (2008) Theory and practice of histological techniques. Elsevier, Churchill, Livingston.

Bresciani J and Høeg JT. (2001) Comparative ultrastructure of the root system in rhizocephalan barnacles (Crustacea: Cirripedia: Rhizocephala). J. Morphol. 249: 9-42.

Cervellione F, McGurk C and Van den Broeck W. (2017) "Perigastric organ": a replacement name for the "hepatopancreas" of Decapoda. J. Crust. Biol. 37: 353-355.

Clark ME, Wolcott TG, Wolcott DL and Hines A. (1999) Intraspecific interference among foraging blue crabs Callinectes sapidus: interactive effects of predator density and prey patch distribution. Mar. Ecol. Prog. Ser. 178: 69-78.

Cuartas EI, Díaz AC and Petriella AM. (2002) Estudio morfológico e histológico del hepatopáncreas del langostino Pleoticus muelleri (Bate) (Crustacea, Penaeoidea). Rev. Invest. Desarr. Pesq. 15:5-13.

De la Cruz-Manjarrez C and Vázquez-López H. (2015) Ethological aspects of the fiddler crab Uca latimanus Rathbun, 1893 in the estuary El Salado, Puerto Vallarta, Jalisco, Mexico. BIOCYT. 8: 557-569.

Edwards DH and Kravitz EA. (1997) Serotonin, social status and aggression. Curr. Opin. Neurobiol. 7: 812-819.

Elofsson R, Laxmyr L, Rosengren E and Hansson C. (1982). Identification and quantitative measurements of biogenic amines and dopa in the central nervous system and haemolymph of the crayfish, Pacifastacus leniusculus (Crustacea). Comp. Biochem. Physiol. 71C: 195-201.

Franceschini-Vicentini IB, Ribeiro K, Papa LP, Marques Junior J, Vicentini CA and Valenti PMCM. (2009) Histoarchitectural features of the hepatopancreas of the Amazon River prawn Macrobrachium amazonicum. Int. J. Morphol. 27: 121-128.

Hammersen F and Sobotta JJ. (1980) Histology: A color atlas of cytology, histology, and microscopic anatomy. Urban and Schwarzenberg, Baltimore.

Haye PAF and Ojeda P. (1998) Metabolic and behavioural alterations in the crab Hemigrapsus 
crenulatus (Milne-Edwards 1837) induced by its acanthocephalan parasite Profilicollis antarcticus (Zdzitowiecki 1985). J. Exp. Mar. Biol. Ecol. 228: 73-82.

Helluy S and Thomas F. (2003) Effects of Microphallus papillorobustus (Platyhelminthes: Trematoda) on serotonergic immunoreactivity and neuronal architecture in the brain of Gammarus insensibilis (Crustacea: Amphipoda). Proc. R. Soc. Lond. B 270: 563-568.

Hines AH and Ruiz GM. (1995) Temporal variation in juvenile blue crab mortality: near shore shallows and cannibalism in chesapeake bay. Bull. Mar. Sci. 57: 884-901.

Hines AH. (2007) Ecology of juvenile and adult blue crabs. In: "The blue crab: Callinectes sapidus", Maryland Sea Grant College University of Mary, Maryland, pp 565-654.

Høeg JT and Lützen J. (1985) Crustacea Rhizocephala. Norwegian University Press, Oslo, Norway.

Høeg JT. (1992) Rhizocephala. In: Microscopic anatomy of the invertebrates, Crustacea. Eds. Harrison FW, Humes AG, Vol. 9, New York, USA, pp 313-345.

Høeg JT and Lützen J. (1995) Life cycle and reproduction in the Cirripedia Rhizocephala. Oceanogr. Mar. Biol. 33: 427-485.

Høeg JT. (1995) The biology and life cycle of the Rhizocephala (Cirripedia). J. Mar. Biol. Ass. UK. 75: 517-550.

Høeg JT and Lützen J. (1996) 1re partie.Super-ordre des Rhizocéphales (Rhizocephala F. Müller, 1862). In: "Traité de Zoologie, Crustacés: Géneralités (suite) etsystématique",Masson, Paris, pp 41-568.

Huber R, Smith K, Delago A, Isaksson K and Kravitz EA. (1997) Serotonin and aggressive motivation in crustaceans: Altering the decision to retreat. Proc. Natl. Acad. Sci. 94: 5939-5942.

Humason GL. (1972) Animal tissue techniques. Freeman WH Company, San Francisco California.

Innocenti G, Vannini M and Galil BS. (1998) Notes on the behaviour of the portunid crab Charybdis longicollis Leene parasitized by the rhizocephalan Heterosaccus dollfusi Boschma. J. Nat. Hist. 32: 1577-1585.

Innocenti G, Pinter N and Galü BS. (2003) Observations on the agonistic behaviour of the swimming crab Charybdis longicollis Leene infected by the rhizocephalan amacle Heterosaccus dollfusi Boschma. Can. J. Zool. 81:173-176.
Jachowski RL. (1974) Agonistic behaviour of the blue crab, Callinectus sapidus Rathbun. Behaviour. 50:232-253.

Johnson PT. (1980) Histology of the blue crab Callinectessapidus: A model for Decapoda. Praeger Publishers, New York, USA.

Khornchatri K, Kornthong N, Saetane J, wan Tinikul Y, Chotwiwatthanakun C, Cummins SF, Hanna PJ and Sobhon P. (2015) Distribution of serotonin and dopamine in the central nervous system of the female mud crab, Scylla olivacea (Herbst). Acta Histochem. 117:196-204.

Laxmyr L. (1984) Biogenic amines and dopa in the central nervous system of decapod crustaceans. Comp. Biochem. Physiol. 77C: 139-143.

McElroy EJ and de Buron I. (2014) Host performance as a target of manipulation by parasites: a metaanalysis. J. Parasitol. 100: 399-410.

McGlone JJ. (1986) Agonistic behavior in food animals: review of research and techniques. J. Anim. Sci. 62: 1130-1139.

Moore J. (1984) Altered behavioural responses in intermediate hosts: an acanthocephalan parasite strategy. Am. Nat. 123: 572-577.

Moore J. (2013) An overview of parasite-induced behavioural alterations - and some lessons from bats. J. Exp. Biol. 216: 11-17.

Livingstone MS, Schaeffer SF and Kravitz EA. (1981) Biochemistry and ultrastructure of serotonergic nerve endings in the lobster. Serotonin and octopamine are contained in different nerve endings. J. Neurobiol. 12: 27-54.

Paniagua R and Nistal M. (1983) Introducción a la histología animal comparada. Labor Universitaria, Barcelona, España.

Pedetta S, Kaczer L and Maldonado H. (2010) Individual aggressiveness in the crab Chasmagnathus: Influence in fight outcome and modulation by serotonin and octopamine. Physiol. Behav. 101: 438-445.

Powell A and Rowley AF.(2008) Tissue changes in the shore crab Carcinus maenas as a result of infection by the parasitic barnacle Sacculina carcini. Dis. Aquat. Org. 80:75-79.

Poulin R. (1994) The evolution of parasite manipulation of host behaviour: a theoretical analysis. Parasitology. 109S: 109-118.

Poulin R. (2010) Parasite manipulation of host behavior: An update and frequently asked questions. 
In: Advances in the study of behavior, Academic Press, Burlington, pp 151-186.

Poulin R. (2013) Parasite manipulation of host personality and behavioral síndromes. J. Exp. Biol. 216:18-26.

Pulgar J, Aldana M, Vergara E and George-Nascimento M. 1995. La conducta de la jaiba estuarina Hemigrapsus crenulatus (Milne-Edwards 1837) en relación al parasitismo por el acantocéfalo Profilicollis antarcticus (Zdzitowiecki 1985) en el sur de Chile. Rev. Chil. Hist. Nat. 68: 439-450.

Ramadevi KRLS, Shyamasundari K and Hanumantha Rao K. (1990) Observation on the hepatopancreas of Ocypoda platytarsis(Milne-Edwards) (Crustacea, Brachyura). Ital. J. Zool. 57: 261-265.

Reichmuth JM, MacDonald J, Ramirez J. and Weis JS. (2011) Fight or flight: an investigation of aggressive behavior and predator avoidance in two populations of blue crabs (Callinectes sapidus Rathbun) in New Jersey. Hydrobiol. 658: 173-182.

Reisser CE and Forward RB Jr. (1991) Effect of salinity on osmoregulation and survival of a rhizocephalan parasite, Loxothylacus panopaei, and its crab host, Rhithropanopeus harrisii. Estuaries. 14:102-106.

Ritchie LE and Høeg JT. (1981) The life history of Lernaeodiscus porcellanae (Cirripedia: Rhizocephala) and co-evolution with its porcellanid host. J. Crust. Biol. 1:334-347.

Robles R, Alvarez F and Alcaraz G. (2002) Oxygen consumption of the crab Callinectes rathbunae parasitized by the rhizocephalan barnacle Loxothylacus texanus as a function of salinity. Mar. Ecol. Prog. Ser. 235:189-194.

Rojas JM and Ojeda FP. (2005) Altered dopamine levels induced by the parasite Profilicollis antarcticus on its intermediate host, the crab Hemigrapsus crenulatus. Biol. Res. 38: 259-66

Russell JD, Walker G and Woollen R. (2000). Observations on two infectious agents found within the roolets of the parasitic barnacle Sacculina carcini. J. Mar. Biol. Ass. UK. 80:373-374.

Sarojini R, Nagabhushanam R, Devi M and Fingerman M. $\left(\begin{array}{ll}1995 & \text { a) Dopaminergic inhibition of }\end{array}\right.$ 5-hydroxytryptamine - stimulated testicular maturation in the fiddler crab, Uca pugilator. Comp. Biochem. Physiol. C. 111: 287-292.

Sarojini R, Nagabhushanam R and Fingerman M. (1995 b) Mode of action of the neurotransmitter 5hydroxytryptamine in stimulating ovarian maturation in the red swamp crayfish, Procambarus clarkii: an in vivo and in vitro study. J. Exp. Zool. 271: 395-400.
Shields JD. (2012) The impact of pathogens on exploited populations of decapod crustaceans. J. Invertebr. Pathol. 110: 211-224.

Smith DRT. (1980) Behavioural interactions between parasites and hosts: Host suicide and the evolution of complex life cycles. Amer. Nat. 116: 7-91.

Sneddon L, Taylor AC, Huntingford FA and Watson DG. (2000) Agonistic behaviour and biogenic amines in shore crabs Carcinus maenas. J. Exp. Biol. 203: 537-545.

Sokal RR and Rohlf FJ. (1981) Biometry. Freeman and Co, New York, USA.

Thompson SN and Kavaliers M. (1994) Physiological bases for parasite-induced alterations of host behaviour. Parasitol. 109: 119-138.

Vázquez-López H, Álvarez-Noguera F and Franco-López J. (2006 a) First record on larval development of the cirripedian parasite Loxothylacus texanus (Cirripedia-Rhizocephala) under laboratory conditions in México. Int. J. Zool. Res. 2: 91-99.

Vázquez-López H, Alvarez F, Franco J, Morán A and Cházaro S. (2006 b) Observations on the behaviour of the dark crab Callinectes rathbunae Contreras parasitized with the rhizocephalan Loxothylacus texanus Boschma. Int. J. Zool. Res. 2: 344-353.

Vázquez-López H. (2010) Affectation of swimming capacity in Callinectes rathbunae (Crustacea: Brachyura) caused by Loxothylacus texanus (Crustacea: Rhizocephala). Res. J. Fish. Hydrobiol. 5: 76-80.

Vázquez-López H, Rocha-Ramírez A, Cházaro-Olvera S, Castillo-Barranco DR, Rodríguez-Varela AC and Cruz-Gómez A. (2012) Shell disease in Callinectes rathbunae Contreras, 1930, parasitized by Loxothylacus texanusBoschma, 1933. J. Fish. Aquat. Sci. 7: 412-421.

Walker RJ. (1984) 5-Hydroxytryptamine in invertebrates. Comp. Biochem. Physiol. 79C: 231-235.

Wardle WJ and Tirpak AJ. (1991) Occurrence and distribution of an outbreak infection of Loxothylacus texanus (Rhizocephala) in blue crabs of Galveston Bay, Texas, with special reference to size and coloration of the parasite's external reproductive structures. J. Crust. Biol. 11: 553-560.

Wu WH and Cooper RL. (2012) Serotonin and synaptic transmission at invertebrate neuromuscular junctions. Exp. Neurobiol. 21: 101-112. 